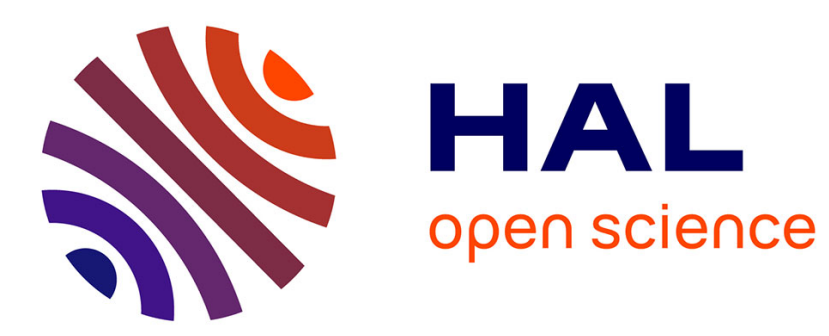

\title{
Marine mammal strandings in the New Caledonia region, Southwest Pacific \\ Philippe Borsa
}

\section{To cite this version:}

Philippe Borsa. Marine mammal strandings in the New Caledonia region, Southwest Pacific. Comptes Rendus Biologies, 2006, 329 (4), pp.277-288. 10.1016/j.crvi.2006.01.004 . ird-00285408

\section{HAL Id: ird-00285408 \\ https://hal.ird.fr/ird-00285408}

Submitted on 5 Jun 2008

HAL is a multi-disciplinary open access archive for the deposit and dissemination of scientific research documents, whether they are published or not. The documents may come from teaching and research institutions in France or abroad, or from public or private research centers.
L'archive ouverte pluridisciplinaire HAL, est destinée au dépôt et à la diffusion de documents scientifiques de niveau recherche, publiés ou non, émanant des établissements d'enseignement et de recherche français ou étrangers, des laboratoires publics ou privés. 
To be cited as:

Borsa P. 2006. - Marine mammal strandings in the New Caledonia region, Southwest Pacific. Comptes Rendus Biologies 329, 277-288.

Marine mammal strandings in the New Caledonia region, South West Pacific

Philippe Borsa

Institut de Recherche pour le Développement, Département des Ressources

Vivantes, 98848 Nouméa cedex, Nouvelle-Calédonie

(phone: +687 260741; fax: +687264326; e-mail:

Philippe.Borsa@noumea.ird.nc) . 


\begin{abstract}
Four hundred twenty three marine mammals, in 72 stranding events, were recorded between 1877 and 2005 in New Caledonia, the Loyalty Islands, and Vanuatu in the southwest Pacific. Sixteen species were represented in this count, including: minke whale, Balaenoptera acutorostrata (1 single stranding), sei whale, $B$. borealis ( 1 single stranding), blue whale, $B$. musculus (1 single stranding), humpback whale, Megaptera novaeangliae (2 single strandings), giant sperm whale, Physeter macrocephalus (18 single strandings, 2 pair strandings), pygmy sperm whale, Kogia breviceps (5 single strandings), dwarf sperm whale, $K$. sima (2 single strandings, 1 triple stranding), Blainville's beaked whale, Mesoplodon densirostris (2 single strandings), short-finned pilot whale, Globicephala macrorhynchus (4 strandings, 56 individuals), melon-headed whale, Peponocephala electra (1 single stranding and 2 mass strandings totalling 231 individuals), common dolphin, Delphinus delphis (1 single stranding), spinner dolphin, Stenella longirostris ( 1 pair stranding and 2 mass strandings of groups of ca. 30 individuals each), Indian Ocean bottlenose dolphin, Tursiops aduncus (2 single strandings), dugong, Dugong dugon (14 single strandings), and New Zealand fur seal, Arctocephalus forsteri (3 single strandings). A stranded rorqual identified as an Antarctic minke whale ( $B$. bonaerensis), with coloration patterns that did not match known descriptions, was also reported. Sei whale was recorded for the first time in the tropical Southwest Pacific region and Antarctic minke whale, melon-headed whale, and Indian Ocean bottlenose dolphin were recorded for the first time in New Caledonia. Strandings of sperm whales were most frequent in the spring, but also occurred in autumn months, suggesting a seasonal pattern of occurrence possibly related to seasonal migration. One stranded humpback whale bore the scars of a killer whale's attack and one dugong was injured by a shark. Scars left by propellers were noted on several stranded animals including one Antarctic minke whale, one pygmy sperm whale, one dwarf sperm whale, and four dugongs. Collisions with vessels were suspected to be a frequent cause of death for dugong.
\end{abstract}

\title{
Résumé
}

Échouages de mammifères marins aux environs de la Nouvelle-Calédonie.

Soixante-douze échouages, impliquant au total 423 individus, sont recensés pour la période 1877-2005, en Nouvelle-Calédonie, aux îles Loyauté et au Vanuatu (Pacifique sud-ouest). Seize espèces sont représentées ici : le petit rorqual, Balaenoptera acutorostrata $(N=1$ individu), le rorqual de Rudolphi, $B$. borealis $(N=1)$, la baleine bleue, B. musculus $(N=1)$, la baleine à bosse, Megaptera novaeangliae $(N=2)$, le cachalot, Physeter macrocephalus $(N$ = 22 dont 2 paires), le cachalot pygmée, Kogia breviceps $(N=5)$, le cachalot nain, $K$. sima ( $N=5$ dont un groupe de 3 ), le mésoplodon de Blainville, Mesoplodon densirostris $(N=2)$, le globicéphale tropical, Globicephala macrorhynchus ( $n=4$ échouages, $N=56)$, le dauphin d'Electre, Peponocephala electra ( $n=3$, dont 2 échouages en masse, concernant 232 individus au total), le dauphin commun, Delphinus delphis $(N=1)$, le dauphin à long bec, Stenella longirostris ( 1 échouage d'une paire d'individus et 2 échouages de ca. 30 individus chacun), le grand dauphin de l'océan Indien, Tursiops aduncus $(N=$ 2), le dugong, Dugong dugon ( $N=14$, échoués ou morts par braconnage), et l'otarie de Nouvelle-Zélande, Arctocephalus forsteri $(N=3)$. L'échouage d'un rorqual identifié comme petit rorqual antarctique (B. bonaerensis), mais possédant des patrons de pigmentation inhabituels chez cette espèce, est également rapporté. Le rorqual de Rudolphi est signalé pour la première fois dans la région tropicale Pacifique sud-ouest. Le petit rorqual antarctique, le dauphin d'Electre et le grand dauphin de l'océan Indien sont signalés pour la première fois dans l'archipel de Nouvelle-Calédonie. Les échouages de cachalots étaient fréquents au printemps et se produisaient également en automne. Cela suggère une présence saisonnière de cette espèce dans les eaux calédoniennes, qui pourrait être liée à ses migrations annuelles. Une baleine à bosse échouée portait les marques d'une attaque par les orques et un dugong, celles d'une attaque par un requin. Les cicatrices dues à des hélices de 
bateau étaient visibles sur plusieurs animaux échoués, dont un petit rorqual antarctique, un cachalot pygmée, un cachalot nain et quatre dugongs. Les collisions avec des bateaux sont soupçonnées d'être un facteur de mortalité significatif chez le dugong.

\section{Introduction}

Despite the importance of marine mammals in oceanic food webs, our knowledge of their distribution, biology, and ecology is still poor. Strandings prove an invaluable source of data for studying the biology and the ecology of marine mammals. Patterns in the strandings of particular species can be related to their distribution, migrations, and reproduction [1]. The present article is geographically restricted to New Caledonia and Vanuatu in the tropical Southwest Pacific, which is one of the data-deficient areas in the world ocean regarding marine mammals [2]. No formal stranding programme has been established to date in New Caledonia and Vanuatu, although biologists based in Nouméa have occasionally documented stranding events in this region [3-10]. Strandings of large marine mammals strike the imagination: they often raise the interest of local newspapers, which therefore may be a useful, albeit sometimes inaccurate, source of data. Based in a large part on the descriptions and photographs published in the New Caledonian newspapers, I compiled all the data on strandings of marine mammals in New Caledonia, the Loyalty Islands and Vanuatu that were available to me, with the following objectives: (1) to raise an updated list of the species known from the area, hence improve our knowledge of their distribution; (2) to detect eventual seasonal patterns in the most frequently stranded species.

\section{Methods}

The Nouméa daily newspapers Nouvelles Calédoniennes reports on such events as strandings from all across the New Caledonia archipelago, in each province of which it has local correspondents, and may also report from vanuatu. The publication of this daily started in 1971. For the period 1971-1997, all the titles of articles published in Nouvelles Calédoniennes have been archived on cardboard files which have been sorted according to one main keyword per article. I manually browsed through these archives using the keywords 'baleine' (whale), 'cachalot' (sperm whale), 'dauphin' (dolphin), 'dugong' (dugong), 'échouage' (stranding), 'plage' (beach), 'poisson' (fish), and 'vache marine' (sea cow). I consulted either the corresponding original issues of Nouvelles Calédoniennes at Bibliothèque Bernheim, Nouméa, or their copies on microfilms at Service Territorial des Archives, Nouméa (STAN). For the period 1998-2001, I browsed the archives of Nouvelles Calédoniennes accessible through Internet (http://archives-lnc.sdv.fr) using the same series of keywords. From January 2002 to December 2005, I checked every issue of this newspaper. A few strandings for the total period (1971-2004), which had gone unnoticed in Nouvelles Calédoniennes were signalled to me on an informal basis. Strandings that occurred before 1971 were known to me from interviews with seniors who were then interested in marine life, unusual events, or photography, eventually pointing to press articles of other journals (Journal Calédonien and Sud Pacific) now archived at STAN.

In several cases where the capture [11] or the strandings [12-21] of cetaceans were reported in the newspapers, identification to species was made possible only after having examined the corresponding series of photographs as the source material. Copies of the photographs examined for the present article have been deposited at IRD, Noumea, and are available upon written request to the Librarian.

The species names used in the present article follow Rice [22].

\section{Results}


The majority of stranding events recorded here (72 in total; Table 1) were of a single animal. Five mass strandings were recorded, two involving consecutively 32 and 199 melon-headed whales (Peponocephala electra) in Vanuatu in 1972, one involving 52 short-finned pilot whales (Globicephala macrorhynchus) in the Loyalty Islands in 1977, and two others involving each a pod of ca. 30 spinner dolphins (Stenella longirostris), one in the Loyalty Islands in 1994, and the other one in Vanuatu in 1995 (Table 1).

In the following I detail the steps that led to the identification of the individuals stranded on the basis of the features accessible from the available documents. The 'eight- to nine-meter-long whale' stranded in Kouaoua Cove in 1977 was described precisely enough [26] to be identified as a minke whale of the white-shoulder form (Balaenoptera acutorostrata, unnamed subspecies [64]). The stranding of another small-sized rorqual (measuring 5-6 $\mathrm{m}$ total length as inferred from its relative proportions to people standing nearby), in the same location in 1993 [27], was recorded on videotape. The main features of this animal were: pointed rostrum, with one median ridge (Fig. 1A,B); small ( $\leq 4.1 \%$ total body length), falcate dorsal fin whose tip was positioned at approximately $74 \%$ total length from snout; about 50 ventral grooves extending to the navel (Fig. 1C). The pigmentation patterns of this whale were: dorsal half almost uniformly grey from snout to flukes, and ventral half white; delineation between the dark pigmentation of the back and the white belly approximately linear, running at mid-body height from the edge of the mouth to the caudal peduncle (Fig. 1A); two parallel, concave forward, lighter grey chevrons visible behind the head; greyish white patches on throat and thorax; right mandible white (Fig. 1B,C); tip of left mandible (the only part of the left side of head visible on the video footage) white; flippers grey above with white anterior margin and white underneath; flukes dark grey to lighter grey on dorsal side, and white with a black margin underneath. The foregoing characteristics point to an Antarctic minke whale (B. bonaerensis) with unusual pigmentation patterns (see [64, 65] for descriptions). The newly described Solomon Sea whale, B. omurai (Wada, Oishi, and Yamada, 2003) [66], was excluded, since careful examination of the suitable excerpts of the video footage revealed no asymmetry in the pigmentation of the ventral side of the throat. The photographs of the rorqual stranded in Thio in 1962 (references in Table 1) depict a sleek, >10 m-long animal, with all-grey back, flanks, flippers, head, and mandibles (Fig. 2). The dorsal fin was relatively tall. Its hind baleen plates were charcoal grey outside, with long, fine, whitish fringes (Fig. 2). The anterior plates were all-whitish. The wide rostrum had a single, prominent ridge and its tip was rounded (Fig. 2). The foregoing observations allowed me to conclude that the animal stranded was a sei whale (B. borealis). The two pictures of the whale stranded in Thio in 1945 (Table 1) unambiguously showed a humpback whale (Megaptera novaeangliae). All but one of the pictures presented along the articles that reported the strandings of giant sperm whales were sufficiently informative to allow me to validate this identification in all cases but one $[19,47-50,52-58,61,62]$. The exception was the pilot whale (Globicephala sp.) stranded in Hienghène in 1965 [13]. The series of photographs corresponding to the report of a 'stranded cetacean' in Gouaro Deva in 2004 [21] showed this was a dwarf sperm whale (Kogia sima), identified to species by its tall dorsal fin relative to total body length. The pilot whales stranded in Ouvéa in 1977 and Isle of Pines in 1997 [39,40] were identified by me as short-finned pilot whales (G. macrorhynchus) based on the shape of flipper, and on its size relative to total length. I also identified as spinner dolphins those dolphins that mass stranded in Ouvéa in 1994 and in Port-Vila in 1995, from the pictures accompanying the articles by Anonymous [15] and Depierre [17,18]. The dolphin that was killed in Nouméa in 1994 [16] was similarly identified as a bottlenose dolphin (Tursiops sp.) from the photographs accompanying the paper. While Rancurel [5] speculates that all three fur seals stranded in 1972-1973 (Table 1) might be inexperienced

'Arctocephalus doriferus' brought to New Caledonia from the southern Tasman Sea by storms, his earlier second-hand description of one individual being dark brown on the back and flanks and greyish on the chest and belly [23] may as well point to $A$. forsteri. The three specimens discovered by Rancurel [23] were eventually identified as $A$. forsteri and not $A$. pusillus doriferus on the basis of distinguishing characters of their skulls [24,67]. All were juveniles 
judging by their small size (between 0.5 - and $1.1 \mathrm{~m}$ total length). Another fur seal was found dead, stranded on the shore of Presqu'île Le Bris in 1990. The whereabouts of the carcass are unknown, but a photograph of the individual was produced in the newspapers [25]. From the picture it can only be identified to genus (Arctocephalus sp.).

Upon examination of its skull (440 mm condylobasal length), I identified as a pygmy sperm whale ( $K$. breviceps) the cetacean whose skeleton was found in Baie de la somme in 2002 [44]. The pygmy or dwarf sperm whale stranded in Ouvéa at an unknown date before 1997 is known and determined to genus from a series of ca. 30 teeth collected on the mandibles (G. Podlejska, pers. comm.).

Most of the strandings were of dead or dying animals. Table 1 also includes strandings of animals that were found alive and which were either killed, or kept in captivity, or released to the open sea. The two live rorquals (Balaenoptera spp.) that stranded in Kouaoua Cove in 1977 and 1993 were pulled back to deeper waters $[26,27]$. The live pygmy sperm whale that stranded in Nouméa in 1997 was euthanized by a deadly injection after failed attempts to salvage it [43]. The pilot whale that stranded on a reef flat in Hienghène in 1965 was captured by villagers, hauled ashore and butchered, as was the short-finned pilot whale stranded in Efate in 1972 [3]. The two spinner dolphins that stranded in Ouvéa in 1972 were pushed back to deeper water. The pod of ca. 30 spinner dolphins that stranded in shallow water in Baie de Takedji in 1994 eventually swam away, leaving one dead animal ashore [15]. Thirty-two individuals of the same species that were trapped in a shallow pool in Erakor lagoon in 1995 were rescued after human intervention, leaving four dead animals behind [17,18]. The dugong (Dugong dugon) stranded in a mangrove channel in Nouméa in 1999 [34] was rescued by local residents, as was the dugong stranded in Nouméa in 2005 [38]. The live New Zealand fur seal that was found on the shore at Touaourou in 1972 was captured and sent to the Noumea aquarium where it died 9 months later, presumably as a result of unsuitable care [23]. Several of the animals stranded had been deliberately killed by poachers: among those were the bottlenose dolphin that was found dead in Baie de Sainte-Marie in 1994 [16], the dugong whose head was recovered in Baie de Sainte-Marie in 1986 [30], and the dugong found dead in Ouano in 2004 (J. Senia, pers. comm.). The New-Zealand fur seal found at Baie de Gu, Isle of Pines, in 1973, was captured by a fisherman with a beach seine net, hauled ashore, killed with a spear, and abandoned on the spot [23].

With a count of $n=20$ strandings (Table 1 ), the giant sperm whale ranked first in stranding occurrence. The dugong ranked second $(n=14)$, the pygmy sperm whale ranked third $(n \geq 5)$, and the short-finned pilot whale ranked fourth $(n \geq 4)$. Regarding the number of individuals stranded, melonheaded whale was by far the most frequent $(N=232)$, followed by spinner dolphin $(N \sim 68)$ and short-finned pilot whale $(N=56)$. Giant sperm whale ranked fourth $(N=22)$.

Strandings of giant sperm whales were most frequent in the spring, from August to December with a marked peak in November, and also occurred in autumn months, from March to May (Table 1). Four of the five strandings of pygmy sperm whale occurred in the spring (from september to December) while the fifth, whose skeleton was discovered in July, could not be dated. All four strandings of fur seals occurred in the winter (Table 1). No such seasonal trend was noted for short-finned pilot whale and dugong (Table 1).

I restricted the temporal (yearly) analysis of stranding events to the period covered by Nouvelles Calédoniennes, that is from 1971 to 2005. A slight increase with time in the total annual number of reported strandings during that period - where I considered the two stranding events reported in November 1972 for melon-headed whale and the three stranding events reported in November 1980 for giant sperm whale (Table 1) as single events - was possible, but this was not significant $\left(y=0.041 x+0.983 ; R^{2}=0.057 ; P>0.05\right)$. A similar positive trend was observed for giant sperm whale $(y=0.018 x+$ $\left.0.101 ; R^{2}=0.064 ; P>0.05\right)$. Recorded stranding events of giant sperm whale varied from 0.3 stranding/year between 1971-1990 to 0.4 stranding/year between 1991-2000, to 1.0 stranding/year for the last five years (2001-2005). Reports of dugong strandings clearly increased during the period considered $(y=0.029$ $\left.x-0.119 ; R^{2}=0.206 ; P<0.01\right)$. 
The possible causes of stranding were inferred from the injuries that were observed in some instances. The minke whale stranded in Kouaoua Cove in 1977 exhibited a deep, one meter-wide wound on the flank [26], but no more precise description was given. The rorqual stranded in Kouaoua Cove in 1993 was injured by a boat propeller [27] but it was not clear whether this occurred before the stranding or at the moment the animal was pulled back to open water. The blue whale that entered Baie du Prony in 2002 was thin, and its condition deteriorated until it was attacked and killed by whaler sharks, Carcharhinus sp. [9]. The humpback whale stranded in Thio in 1945, which was ca. $11 \mathrm{~m}$ long, had its fluke severed and exhibited on the abdomen deep wounds whose shape and size (ca. $1 \mathrm{~m}$ wide) were characteristic of killer whale (Orcinus orca) bites. Superficial-to-deep, linear, parallel scars characteristic of boat propellers were observed on four stranded dugongs (in Nouméa in 1974, 2002, and 2005; in Koumac in 2000), on the pygmy sperm whale stranded on Plum Beach in 1985, and on one of the three dwarf sperm whales stranded on Plum Beach in 2005. The dugong stranded in Tina in 2005 had been hit on the flank by, presumably, the bow of a vessel (P. Borsa, personal observation). The dugong stranded in Ouano in 1999 was reported to have been injured by a stingray [33]. The dugong stranded in a mangrove channel in Nouméa in 1999 exhibited wounds inflicted by shark bites on its caudal peduncle [34]: I hypothesize that because of its injuries the animal was too weak to swim actively and was taken upstream by the rising tide, or it trapped itself in shallow water while attempting to escape to its predator.

\section{Discussion}

Thirteen cetacean species [minke whale, humpback whale, giant, pygmy and dwarf sperm whales, Blainville's beaked whale (Mesoplodon densirostris), shortfinned pilot whale, Risso's dolphin (Grampus griseus), killer whale, false killer whale (Pseudorca crassidens), pan-tropical spotted dolphin (Stenella attenuata), spinner dolphin, and bottlenose dolphin] have been earlier listed for New Caledonian waters by Garrigue and Greaves [68]. However, that list overlooked several species earlier mentioned in the scientific literature, including Bryde's whale (Balaenoptera edeni or B. brydei) [2], and common dolphin (Delphinus delphis) $[2,22,69]$. Bryde's whale is known in New Caledonian waters from a catch by a Japanese whaling vessel in 1957 [2]. While the present survey refers to a specimen of common dolphin found stranded on Isle of Pines before 1877 (Table 1), Heyning and Perrin [69] inferred the presence of that species in the New Caledonian waters from a description and unpublished illustration of an animal collected by Forster [70] near New Caledonia and described as D. forsteri by Gray [71]. Heyning and Perrin [69] synonymized $D$. forsteri with $D$. delphis on the basis of color pattern (white patches on the dorsal fin and flippers) and tooth count (W.F. Perrin, pers. comm.).

Blue whale was another species not included in earlier lists $[2,68]$. The presence of a blue whale in the southern lagoon of New Caledonia's Grande Terre in 2002 [9] was the first occurrence of that species reported for the tropical Southwest Pacific since a sighting survey in the Solomon Islands in $1957[2,72]$.

Two species of bottlenose dolphin are currently recognised (Indian Ocean bottlenose dolphin, Tursiops aduncus, and common bottlenose dolphin, $T$. truncatus), based on anatomical features. This distinction has been recently confirmed from the geographically overlapping distribution of separate mitochondrial lineages, an Indo-Pacific one characterizing the Indian Ocean bottlenose dolphin, and a worldwide one characterizing the common bottlenose dolphin [73,74]. The two skulls of bottlenose dolphin that were recovered from strandings in New Caledonia and deposited at MNHN were examined by D. Robineau and identified by him as $T$. aduncus (Table 1 ). Although the two species of bottlenose dolphin are difficult to distinguish at sea [75], I was able to identify $T$. truncatus in New Caledonian waters in one instance [off the southern barrier reef $\left.\left(22^{\circ} 35^{\prime} \mathrm{S}, 166^{\circ} 28^{\prime} \mathrm{E}\right) ; 02 \mathrm{Feb} .2002\right]$ where two bottlenose dolphins rode the bow of research vessel Alis for about three minutes. The large size (ca. $3 \mathrm{~m}$ ), the heavily built body, and the short beak of these 
individuals undoubtedly pointed to $T$. truncatus. Hence, both Tursiops species are present in New Caledonia.

Two recent strandings of Blainville's beaked whale have been recorded so far in the New Caledonia-Vanuatu area, where this species is also known from two rostra collected on the seafloor and one live sighting [10]. Blainville's beaked whale is probably the most abundant mesoplodont in the Tropics [76]. Risso's dolphin has been reported from around New Caledonia based on an opportunistic sighting [68]. A photograph published in Nouvelles Calédoniennes [11] provides additional evidence to the presence of this species in New Caledonian waters, as it depicted a young Risso's dolphin hauled aboard longliner Toho $V$ after it was caught on a baited hook off the Chesterfield Islands in the Coral sea in December 1996. Recent sightings have confirmed the regular presence, in the Loyalty Islands, of Risso's dolphin, as well as melon-headed whale and pan-tropical spotted dolphin (J.-L. Menou, F. Abrahami, pers. Comm; P. Borsa, unpubl.). Killer whales have been reported from off the barrier reef in the winter, and false killer whales are regularly sighted offshore and have also been sighted inside the southern lagoon of New

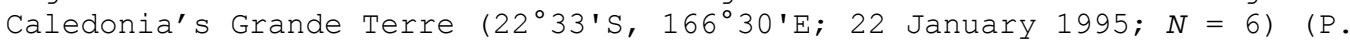
Borsa, unpubl.).

The new information presented in this article extends the total number of cetacean species in the New Caledonia-Vanuatu area to 20, and its total number of marine mammal species to 22. The presence of sei whale is here reported for the first time in the tropical Southwest Pacific region. Antarctic minke whale, melon-headed whale, and Indian-Ocean bottlenose dolphin are reported for the first time in New Caledonia, although these species have already been reported from the Southwest Pacific region. Antarctic minke whale seasonally occurs off eastern Australia, including the southernmost portion of the Great Barrier Reef [64]. Melon-headed whale was reported from Vanuatu [3]. Indian Ocean bottlenose dolphin is common in the inshore waters of Queensland $($ e.g. [77]).

The marine mammal fauna of the New Caledonia-Vanuatu area includes mainly tropical to warm-temperate species (Bryde's whale, pygmy and dwarf sperm whales, Blainville's beaked whale, short-finned pilot whale, false killer whale, melon-headed whale, common dolphin, pan-tropical spotted dolphin, spinner dolphin, Indian-Ocean bottlenose dolphin, and dugong), tropical to cold-temperate species (sei whale, Risso's dolphin, and bottlenose dolphin), cosmopolitan species (minke whale, blue whale, humpback whale, giant sperm whale, and killer whale), one species distributed in the temperate to circumpolar latitudes of the southern hemisphere (Antarctic minke whale), and one species mostly restricted to southern Australia and New Zealand (New Zealand fur seal). Five of the foregoing species (minke whale, Antarctic minke whale, sei whale, humpback whale, and giant sperm whale) are known to undertake seasonal migrations between their summer breeding areas in the tropics and feeding grounds in the higher latitudes [65,78-81]. However, the migrations of giant sperm whale are not as well understood as those of most baleen whales [81] and the migration patterns of sei whale and blue whale in the Southwest Pacific are not documented [2]. Reeves et al. [2] reported the presence of large concentrations of blue whale off the Solomon Islands in August 1957. Data from illegal Soviet whaling expeditions map the distribution of pygmy blue whale as encompassing much of the Indian Ocean but also extending into the Indo-Malay archipelago and to the Tasman Sea [2]. Despite a paucity of records [2,9], blue whales may therefore be a regular occurrence in the tropical Southwest Pacific, unless they were depleted by illegal catches that may have occurred after 1957 in this region. Rice [22] mentions New Zealand fur seal as a 'vagrant to Nouvelle-Calédonie'. New Zealand fur seals regularly haul out at Three Kings Island off the northern tip of New Zealand [22], which is ca. $1400 \mathrm{~km}$ distant from the southern tip of New Caledonia.

Seasonal trends in stranding frequency were found in some of the species reported here. Strandings of giant sperm whales were most frequent in the spring, and also occurred in autumn months. Assuming that the rate of strandings reflects the abundance of animals offshore, this seasonal pattern suggests variation in abundance, possibly related to seasonal migration.

Bull sperm whales undertake annual migrations to the Antarctic at the onset of the austral summer while females and calves are thought to remain in the 
tropical and temperate waters year-round [81]. The New Caledonia area thus appears to be either a passage to and from the southern summering areas of sperm whales, or an area where sperm whales concentrate seasonally, or both. Interestingly, at least four of the five strandings of the poorly known pygmy sperm whale occurred in New Caledonia in the spring, suggesting a seasonal peak of abundance for this species in New Caledonian waters, which in turn may also indicate annual migration. Juvenile New Zealand fur seals apparently occur in New Caledonia in the winter. This indicates a seasonal northward dispersal pattern that may be dictated by thermoregulatory constraints, or by intraspecific competition for food.

The data presented here showed that humpback whales in the New Caledonia area are vulnerable to attacks by killer whales. Killer whale attacks on large cetaceans have long been documented, to the point that it is widely believed that baleen whales and sperm whales are major preys of killer whales [82,83]. Dugongs are known to be preyed upon by large sharks, such as the tiger shark (Galeocerdo cuvieri) [84]. Collisions with ships are currently considered to be a major cause of mortality for large cetaceans [85]. Collisions between vessels and marine mammals have been recently recorded in New Caledonia: a large whale, possibly a humpback whale, was hit by the propeller of Research Vessel Alis (a 29-m trawler) cruising at 9 knots in the northern lagoon of New Caledonia (19 $\left.52^{\prime} \mathrm{S}, 163^{\circ} 57^{\prime} \mathrm{E}\right)$ on 8 August 1994 (P. Borsa, unpubl. observation); an unidentified whale was hit by the 44-metre fast catamaran Marie-Hélène cruising at ca. 20 knots in Canal Woodin $\left(22^{\circ} 24^{\prime} \mathrm{S}\right.$, $\left.166^{\circ} 50^{\prime} \mathrm{E}\right)$ in March 1997 [86]; another unidentified whale was hit by the same ship in Passe de la Sarcelle $\left(22^{\circ} 27^{\prime} \mathrm{S}, 1^{\circ} 167^{\circ} 4^{\prime} \mathrm{E}\right)$ in February 1998 [87]; and a humpback whale calf was hit by the bow of a sailing boat in the southwestern lagoon in August 2002 [88]. It is not known whether these injuries were lethal, although the damage to the hull of Marie-Hélène in February 1998 was such that this strike obviously caused severe injury to the whale. Lethal strikes of pygmy sperm whale, dwarf sperm whale, and dugong were reported in the present survey. The other causes of injury or death for stranded animals are unknown, but no thorough autopsy (flensing to the bone) seems to have been practised ever in New Caledonia or Vanuatu. Such a protocol should be followed to detect eventual ship strikes that cause injuries that are not visible from the external aspect of the stranded animals.

The International Union for the Conservation of Nature classifies the dugong as vulnerable to extinction at the global scale on the basis of anecdotal evidence of declines in its abundance throughout most of its range [89]. There is widespread admission that dugong populations have been declining in New Caledonia in the last decades [90,91]. Since 1963 the dugong is a fully protected species in New Caledonia although on special traditional ceremonies catch permits are delivered on a case-by-case basis to Melanesian tribes upon their written request. The present stranding data uncovered two factors currently affecting the dugong population of New Caledonia: poaching, and maritime traffic. The significant increase in reported dugong strandings may indeed reflect higher mortality in relation with increased maritime traffic.

\section{Note added in proof}

Two additional strandings of cetaceans were communicated to me after this manuscript was sent to press. Photographs subsequently published in Nouvelles Calédoniennes $[92,93]$ allowed the identification of the stranded animals to species. Three pygmy killer whales(Feresa attenuata) were found live-stranded in the mangrove near La Coulée $\left(22^{\circ} 15^{\prime} \mathrm{S} ; 1^{\circ} 36^{\circ} 33^{\prime} \mathrm{E}\right)$ on 30 January 2006 ; two of the animals were rescued by local residents, while the third one, a 2.45-mlarge male, was euthanized by deadly injection [92]. The second stranding was of another pygmy killer whale, found dead in the 'Baie de Toro' $\left(22^{\circ} 09^{\prime} \mathrm{S}\right.$;

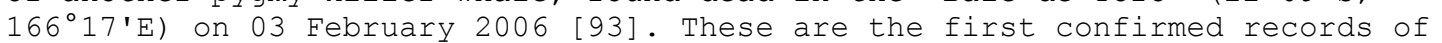
pygmy killer whale in New Caledonia, and also the first for the Southwest Pacific [2], now raising the total number of marine mammal species occurring in the New Caledonia-Vanuatu region to 23. 


\section{Acknowledgements}

I wish to thank N. Baillon, A. Bonnenfant, B. Bonua, G. Callejon, M. Fels, S. Gil, H. Girard, P. Larue, C. Ledru, M. Le Pêchoux, M. Martin, T. Martinez, J.L. Menou, I. Perrin, F. Pierre, O. Pierre, G. Podlejska, P. Primot, R. Proner, S. Ribot, B. Richer de Forges, J. Rolland, J. Senia, P. Tirard, and W. Wendt for the useful informations they kindly provided to me. M. Tiburzio allowed me browsing through the files of Nouvelles Calédoniennes. I. Kurtovitch and K. Dervieux of Service Territorial des Archives, Nouméa, greatly facilitated access to archived newspapers and photographs. I am grateful to Jean-Michel Boré of IRD, who assisted in editing the figures, and to N. Boiteux and E. Folcher for their help in mapping the strandings. I am especially grateful to Pierre Larue for his continued interest in the present research, to W.F. Perrin and D.W. Rice for helpful precisions and for their encouragements, and to D. Robineau both for the excellent documents he forwarded to me and for stimulating discussions.

\section{References}

[1] W.F. Perrin, J.R. Geraci, Stranding, in: W.F. Perrin, B. Würsig, J.G.M. Thewissen (Eds.), The Encyclopedia of Marine Mammals, Academic Press, San Diego, 2002, pp. 1192-1197.

[2] R.R. Reeves, S. Leatherwood, G.S. Stone, L.G. Eldredge, Marine mammals in the area served by the South Pacific Regional Environment Programme (SPREP), SPREP, Apia, 1999.

[3] P. Rancurel, Quelques échouages de cétacés survenus dans le Sud-Ouest Pacifique en 1972, Bull. Pac. Sud 23 (1973) 12-15.

[4] P. Rancurel, Echouage en masse du cétacé Peponocephala electra aux NouvellesHébrides, Biol. Conserv. 6 (1974) 3.

[5] P. Rancurel, Echouages d'otaries à fourrure dans le sud de la Nouvelle-Calédonie, Mammalia 39 (1975) 499-504.

[6] D. Robineau, P. Rancurel, Sur deux spécimens du genre Kogia (Cetacea, Physeteridae) en Nouvelle-Calédonie, Z. Säugetierk. 46 (1981) 56-58.

[7] J.-P. Sylvestre, On a specimen of pygmy sperm whale Kogia breviceps (Blainville, 1838) from New Caledonia, Aquat. Mamm. 14 (1988) 76-77.

[8] P. Bustamante, C. Garrigue, L. Breau, F. Caurant, W. Dabin, J. Greaves, R. Dodemont, Trace elements in two odontocete species (Kogia breviceps and Globicephala macrorhynchus) stranded in New Caledonia (South Pacific), Env. Pollut. 124 (2003) 263-271.

[9] P. Borsa, G. Hoarau, A juvenile pygmy blue whale (Cetacea: Balaenopteridae) in the inshore waters of New Caledonia, Pac. Sci. 58 (2004) 579-584.

[10] P. Borsa, D. Robineau, Blainville's beaked whale in New Caledonia, Pac. Sci. 59 (2005) 467-472.

[11] Anonymous, Un bébé globicéphale pour l'ORSTOM, Nouv. Calédoniennes 7688 (1996) 10.

[12] Anonymous, Une baleine échouée, Sud Pacific 103 (1963) 5.

[13] Anonymous, Un cachalot échoué près de Hienghène, J. Calédonien 47 (1965) 12.

[14] B. Sylvano, Un bébé dauphin s'échoue à Magenta, Nouv. Calédoniennes 6660 (1993) 1, 10 .

[15] Anonymous, Ouvéa: une trentaine de cétacés échoués une matinée en baie de Takedji, Nouv. Hebdo 308 (1994) 3.

[16] Anonymous, La triste fin du dauphin, Nouv. Calédoniennes 7019 (1994) 1, 8.

[17] F. Depierre, Vingt-huit dauphins pris au piège à Port-Vila, Nouv. Calédoniennes 7097 (1995) 32-33.

[18] F. Depierre, Les dauphins d'Erakor sont libres, Nouv. Calédoniennes 7100 (1995) 28.

[19] M. Martin, Une baleine retrouvée morte à Touho, Nouv. Calédoniennes (suppl.) (1999) $20-21$.

[20] Anonymous, Un dauphin échoué à Saint-Louis, Nouv. Calédoniennes 9028 (2001) 5.

[21] Anonymous, Un cétacé échoué au nord de Bourail, Nouv. Calédoniennes 9891 (2004) 1, 6 .

[22] D.W. Rice, Marine mammals of the world, systematics and distribution, Soc. Mar. Mammal., Spec. Publ. 4, Allen Press, Lawrence KS, 1998.

[23] P. Rancurel, Compte rendu de mission à l'île des Pins (3 octobre 1973) (Echouage otarie et calmars), ORSTOM, Nouméa, 1973, 9 p.

[24] J.E. King, On the identity of three young fur seals (genus Arctocephalus) stranded in New Caledonia, Beaufortia 25 (1976) 97-105. 
[25] A. Cler, Une otarie s'est échouée à La Foa, Nouv. Calédoniennes 5789 (1990) 13.

[26] Anonymous, Une baleine s'échoue à Kouaoua, Nouv. Calédoniennes 1866 (1977) 3.

[27] Anonymous, Kouaoua : les habitants du village au secours d'une baleine échouée, Nouv. Calédoniennes 6637 (1993) 1, 3.

[28] Anonymous, Une vache marine au Rocher à la Voile, Nouv. Calédoniennes 1014 (1974) 3 .

[29] Anonymous, En direct du lagon, Nouv. Calédoniennes 3476 (1982) 42.

[30] Anonymous, Pauvre dugong, Nouv. Calédoniennes 4445 (1986) 2.

[31] R.C. Fournier, L'amour vache, Nouv. Hebdo 259 (1993) 16-18.

[32] P.E. Marit, Une vache marine échouée au Kuendu Beach, Nouv. Calédoniennes 7012 (1994) 13 .

[33] Anonymous, Une vache marine s'échoue à La Foa, Nouv. Calédoniennes 8428 (1999) 12.

[34] P. Frédière, Une vache marine sauvée de l'échouage, Nouv. Calédoniennes 8444 (1999) 1,4 .

[35] Anonymous, À la Baie des Requins, une vache marine échouée sur la berge, Nouv. Calédoniennes 8679 (2000) 15 .

[36] Anonymous, Magenta : une jeune vache marine échouée sur la plage, Nouv. Calédoniennes 9257 (2002) 1, 11.

[37] Anonymous, Un dugong échoué à Tina, Nouv. Calédoniennes 10326 (2005) 10.

[38] S. Ribot, Nouméa : un dugong échoué sur la plage, Nouv. Calédoniennes 10399 (2005) 4.

[39] P. Godard, Le mémorial calédonien, tome VIII 1977-1981, Éditions d'Art Calédoniennes, Nouméa, 1982.

[40] D. Delers, Deux globicéphales s'échouent à l'île des Pins, Nouv. Calédoniennes 7922 (1997) $1,6$.

[41] Anonymous, Le petit cachalot est mort, Nouv. Calédoniennes 4300 (1985) 1, 3.

[42] Anonymous, Un cachalot pygmée échoué à Vieux Touho, Nouv. Calédoniennes 7925 (1997) 17 .

[43] D. Delers, Un cachalot pygmée vient mourir sur la plage, Nouv. Calédoniennes 7929 (1997) 14

[44] H. Girard, Un cétacé s'échoue à Prony, Nouv. Calédoniennes 9409 (2002) 3.

[45] S. Ribot, Bourail : le cétacé échoué était un cachalot nain, Nouv. Calédoniennes $9893(2004) 22$

[46] Anonymous, La mort d'un cachalot, Sud Pacific 120 (1964) 32.

[47] Anonymous, À Tao: un cachalot en pâture aux requins, J. Calédonien 79 (1966) 1.

[48] Anonymous, Un bébé cachalot échoué à Nouville, Nouv. Calédoniennes 1152 (1975) 1, 18.

[49] Anonymous, Deux cachalots échoués à Poindimié, Nouv. Calédoniennes 2837 (1980) 1-2.

[50] Anonymous, Deux nouveaux cachalots sur la côte est; aux explosifs impuissants on a préféré le feu, Nouv. Calédoniennes 2839 (1980) 24.

[51] Anonymous, Un cachalot mort assailli par les requins, Nouv. Calédoniennes 5409 (1989) 5 .

[52] Y. Delauw, Un cachalot gît échoué au large de Bourail, Nouv. Hebdo 66 (1989) 34.

[53] M. Le Pêchoux, Un énorme cachalot échoué sur le récif, Nouv. Calédoniennes 7319 (1995) 17

[54] O. Bonetti, Le festin des requins, Nouv. Calédoniennes 8004 (1998) 1, 4-5.

[55] Anonymous, Un cachalot échoué sert de festin aux requins, Nouv. Calédoniennes 8310 (1999) 6.

[56] Anonymous, Un cachalot échoué sur le platier de l'îlot Tangadiou, Nouv. Calédoniennes 9136 (2001) 26.

[57] Anonymous, Une baleine échouée à l'îlot Bayes, Nouv. Calédoniennes 9186 (2001) 7.

[58] S. Travers, Un cachalot échoué en baie de Saint-Vincent, Nouv. Calédoniennes 10046 (2004) 1, 5 .

[59] Anonymous, Le cachalot échoué étudié par les scientifiques, Nouv. Calédoniennes $10050(2004) 6$.

[60] Anonymous, Des hypothèses sur 1'échouage des cétacés, Nouv. Calédoniennes 10195 (2005) 8 .

[61] Anonymous, Des requins-tigres font festin autour d'un cachalot échoué, Nouv. Calédoniennes 10065 (2004) 23.

[62] Anonymous, Ouvéa: des dauphins sur la plage, Nouv. Calédoniennes 6808 (1994) 10.

[63] Anonymous, Deux mammifères marins se sont échoués au Phare, Le Galibi a remorqué les cadavres au large, Nouv. Calédoniennes 2641 (1979) 3.

[64] P. Arnold, H. Marsh, G. Heinsohn, The occurrence of two forms of minke whale in east Australian waters with a description of external characters of the diminutive or dwarf form, Sci. Rep. Whales Res. Inst. Tokyo 38 (1987) 1-46.

[65] W.F. Perrin, R.L. Brownell Jr., Minke whales Balaenoptera acutorostrata and $B$. bonaerensis, in: W.F. Perrin, B. Würsig, J.G.M. Thewissen (Eds.), The Encyclopedia of Marine Mammals, Academic Press, San Diego, 2002, pp. 750-754. 
[66] S. Wada, M. Oishi, T.K. Yamada, A newly discovered species of living baleen whale, Nature 426 (2003) 278-281.

[67] J.E. King, Seals of the World, second ed., British Museum of Natural History, London, 1983.

[68] C. Garrigue, J. Greaves, Cetacean records for the New Caledonian area (Southwest Pacific Ocean), Micronesica 34 (2001) 27-33.

[69] J.E. Heyning, W.F. Perrin, Evidence for two species of common dolphins (genus Delphinus) from the eastern North Pacific, Nat. Hist. Mus. Los Angeles County Contrib. Sci. 442 (1994) 1-35.

[70] J.R. Forster, Descriptiones animalium quae in intinere ad maris australis terras per annos 1772, 1773 et 1774 suscepto collegit. Herico Lichtenstein, Akademie der Wissenschaften, Berlin, 1844, xiii + 424 p.

[71] J.E. Gray, on the cetaceous animals, in: J. Richardson, J.E. Gray (Eds.), Mammalia, Birds, in: The Zoology of the Voyage of H.M.S. Erebus and Terror, vol. 1, E.W. Janson, London, 1846, pp. 13-53.

[72] IWC, Report of the scientific committee, Rep. Int. Whaling Commun. 46 (1996) 49236.

[73] R.G. LeDuc, W.F. Perrin, A.E. Dizon, Phylogenetic relationships among the delphinid cetaceans based on full cytochrome $b$ sequences, Mar. Mamm. Sci. 15 (1999) 619-648.

[74] L.M. Möller, L.B. Beheregaray, Coastal bottlenose dolphins from southeastern Australia are Tursiops aduncus according to sequences of the mitochondrial DNA control region, Mar. Mamm. Sci. 17 (2001) 249-263.

[75] R.S. Wells, M.D. Scott, Bottlenose dolphins, Tursiops truncatus and T. aduncus, in: W.F. Perrin, B. Würsig, J.G.M. Thewissen (Eds.), The Encyclopedia of Marine Mammals, Academic Press, San Diego, 2002, pp. 122-128.

[76] R.L. Pitman, Mesoplodont Whales, in: W.F. Perrin, B. Würsig, J.G.M. Thewissen (Eds.), The Encyclopedia of Marine Mammals, Academic Press, San Diego, 2002, pp. $738-742$.

[77] B.L. Chilvers, P.J. Corkeron, Association patterns of bottlenose dolphins (Tursiops aduncus) off Point Lookout, Queensland, Australia, Can. J. Zool. 80 (2002) 973-979.

[78] F. Kasamatsu, S. Nishiwaki, H. Ishikawa, Breeding areas and southbound migrations of southern minke whales, Balaenoptera acutorostrata, Mar. Ecol. Prog. Ser. 119 (1995) 1-10.

[79] P.J. Clapham, J.G. Mead, Megaptera novaeangliae, Mamm. Species 604 (1999) $1-9$.

[80] J. Horwood, Sei whale Balaenoptera borealis, in: W.F. Perrin, B. Würsig, J.G.M. Thewissen (Eds.), The Encyclopedia of Marine Mammals, Academic Press, San Diego, 2002 , pp. 1069-1071.

[81] H. Whitehead, Sperm whale Physeter macrocephalus, in: W.F. Perrin, B. Würsig, J.G.M. Thewissen (Eds.), The Encyclopedia of Marine Mammals, Academic Press, San Diego, 2002, pp. 1165-1172.

[82] A.M. Springer, J.A. Estes, G.B. van Vliet, T.M. Williams, D.F. Doak, E.M. Danner, K.A. Forney, B. Pfister, Sequential megafaunal collapse in the North Pacific Ocean: an ongoing legacy of industrial whaling?, Proc. Natl Acad. Sci. USA 100 (2003) $12223-12228$.

[83] P.J. Corkeron, R.C. Connor, Why do baleen whales migrate?, Mar. Mamm. Sci. 15 (1999) 1228-1245.

[84] M.R. Heithaus, The biology of tiger sharks, Galeocerdo cuvier, in Shark Bay, Western Australia: sex ratio, size distribution, diet, and seasonal changes in catch rates, Environ. Biol. Fishes 61 (2001) 25-36.

[85] D.W. Laist, A.R. Knowlton, J.G. Mead, A.S. Collet, M. Podesta, Collisions between ships and whales, Mar. Mamm. Sci. 17 (2001) 35-75.

[86] M. Martin, Sachez observer les baleines, Nouv. Calédoniennes 7780 (1997) 10.

[87] Anonymous, Le Marie-Hélène heurte une baleine, Nouv. Calédoniennes 8038 (1998) 4.

[88] H. Girard, Un baleineau percuté par un voilier, Nouv. Calédoniennes 9409 (2002) 3.

[89] H. Marsh, Dugong Dugong dugon, in: W.F. Perrin, B. Würsig,J.G.M. Thewissen (Eds.), The Encyclopedia of Marine Mammals,Academic Press, San Diego, 2002, pp. 344-347.

[90] J.-P. Das, Estimation préliminaire concernant la présence de mammifères marins en Nouvelle-Calédonie. CEMMEN, Nouméa, 1993, unpubl.

[91] S. Morel, Braconnage maritime : le lagon sans défense, Nouv. Calédoniennes 10263 (2005) 2-3.

[92] Y. Doucet, I. Olhagaray, C. Cochin, J. Samperez, Orques en détresse au Mont-Dore, Nouv. Calédoniennes 10449 (2006) 1-3.

[93] Anonymous, Une orque naine retrouvée morte à Païta, Nouv. Calédoniennes 10451 (2006) 4 . 
Table 1 Strandings of marine mammals in New Caledonia (NC), Loyalty Islands (LI) and Vanuatu (VA), with dates, numbers of animals involved $(N)$, references for data, and other documents available (vouchers). MHM: Musée de l'Histoire Maritime, Nouméa; MMT: Musée de la Mine, Thio; MNHN: Muséum National d'Histoire Naturelle, Paris; ZMA: Zoological Museum, University of Amsterdam.

\begin{tabular}{|c|c|c|c|c|c|}
\hline $\begin{array}{l}\text { Species, } \\
\text { Location }\end{array}$ & Coordinates & Date & $N$ & References & Vouchers \\
\hline \multicolumn{6}{|l|}{ Arctocephalus forsteri } \\
\hline NC: Baie de Gadji, Isle of Pines & $22^{\circ} 33^{\prime} \mathrm{S} ; 167^{\circ} 26^{\prime} \mathrm{E}$ & -- Aug 1972 & 1 & {$[23,24]$} & Skull, ZMA 17.797 \\
\hline NC: Touaourou, Yaté & $22^{\circ} 11$ 'S; $166^{\circ} 59^{\prime} \mathrm{E}$ & -- Aug 1972 & 1 & {$[23,24]$} & Skull, ZMA 17.798; photograph \\
\hline NC: Baie de Gu, Isle of Pines & $22^{\circ} 33^{\prime} \mathrm{S} ; 167^{\circ} 26^{\prime} \mathrm{E}$ & 21 Sep 1973 & 1 & {$[23,24]$} & - \\
\hline \multicolumn{6}{|l|}{ Arctocephalus sp. } \\
\hline NC: Presqu'île Le Bris, La Foa & $21^{\circ} 49^{\prime} \mathrm{S} ; 161^{\circ} 46^{\prime} \mathrm{E}$ & 19 Aug 1990 & 1 & {$[25]$} & Photograph \\
\hline \multicolumn{6}{|l|}{ Balaenoptera acutorostrata, dwarf form } \\
\hline NC: Baie de Kouaoua & $21^{\circ} 25^{\prime} \mathrm{S} ; 165^{\circ} 51^{\prime} \mathrm{E}$ & 19 Aug 1977 & 1 & {$[26]$} & - \\
\hline \multicolumn{6}{|l|}{ Balaenoptera bonaerensis } \\
\hline NC: Baie de Kouaoua & $21^{\circ} 25^{\prime} \mathrm{S} ; 165^{\circ} 51^{\prime} \mathrm{E}$ & 27 Jun 1993 & $1^{1}$ & {$[27]$} & Video footage at MNHN; Fig. 1 \\
\hline \multicolumn{6}{|l|}{ Balaenoptera borealis } \\
\hline NC: Baie de Tamanou, Thio & $21^{\circ} 40^{\prime} \mathrm{S} ; 166^{\circ} 20^{\prime} \mathrm{E}$ & 20 May 1962 & 1 & [12]; M. Fels (pers. comm.) & $\begin{array}{l}\text { Photographs, including MMT 04-109 } \\
\text { and Fig. } 2\end{array}$ \\
\hline \multicolumn{6}{|l|}{ Balaenoptera musculus } \\
\hline NC: Baie de la Somme & $22^{\circ} 20^{\prime} \mathrm{S} ; 166^{\circ} 49^{\prime} \mathrm{E}$ & 29 Jan 2002 & 1 & {$[9]$} & Photographs; skull at MHM; skin sampl $\epsilon$ \\
\hline \multicolumn{6}{|l|}{ Delphinus delphis } \\
\hline NC: Isle of Pines & - & $\leq 1877$ & 1 & D. Robineau (pers. comm.) & Skull, MNHN 1884-261 \\
\hline \multicolumn{6}{|l|}{ Dugong dugon } \\
\hline NC: Rocher à la Voile, Nouméa & $22^{\circ} 18^{\prime} \mathrm{S} ; 166^{\circ} 26^{\prime} \mathrm{E}$ & 20 Oct 1974 & $1^{1,2}$ & {$[28]$} & Photographs \\
\hline NC: Anse Vata, Nouméa & $22^{\circ} 18^{\prime} \mathrm{S} ; 166^{\circ} 26^{\prime} \mathrm{E}$ & 22 Dec 1982 & 1 & [29] & Photograph \\
\hline NC: Baie de Sainte-Marie, Nouméa & $22^{\circ} 17^{\prime} \mathrm{S} ; 166^{\circ} 27^{\prime} \mathrm{E}$ & 09 Mar 1986 & 1 & {$[30]$} & Photograph \\
\hline NC: Ilot Mathieu, Baie de Saint-Vincen & $22^{\circ} 05^{\prime} \mathrm{S} ; 166^{\circ} 06^{\prime} \mathrm{E}$ & ---- 1990 & 1 & J.-L. Menou (pers. comm.) & - \\
\hline NC: Baie de Ouano & $21^{\circ} 51^{\prime} \mathrm{S} ; 165^{\circ} 49^{\prime} \mathrm{E}$ & -- Feb 1993 & 1 & {$[31]$} & Skull \\
\hline NC: Plage de Kuendu & $22^{\circ} 16^{\prime} \mathrm{S} ; 166^{\circ} 23^{\prime} \mathrm{E}$ & 20 Sep 1994 & $1^{1}$ & {$[32]$} & Photograph \\
\hline NC: Baie de Ouano & $21^{\circ} 51^{\prime} \mathrm{S} ; 165^{\circ} 49^{\prime} \mathrm{E}$ & -- Jun 1999 & 1 & {$[33]$} & Photograph \\
\hline NC: Ko Wé Kara, Nouméa & $22^{\circ} 15^{\prime} \mathrm{S} ; 166^{\circ} 27^{\prime} \mathrm{E}$ & 03 Jul 1999 & 1 & {$[34]$} & Photographs \\
\hline NC: Baie des Requins, Koumac & $20^{\circ} 44^{\prime} \mathrm{S} ; 164^{\circ} 25^{\prime} \mathrm{E}$ & -- Apr 2000 & $1^{1}$ & [35] & Photograph \\
\hline NC: Baie Papaye & $22^{\circ} 11$ 'S; $166^{\circ} 19^{\prime} \mathrm{E}$ & -- Feb 2002 & 1 & - & - \\
\hline NC: Baie de Magenta, Nouméa & $22^{\circ} 16^{\prime} \mathrm{S} ; 166^{\circ} 28^{\prime} \mathrm{E}$ & 04 Mar 2002 & $1^{1,2}$ & {$[36]$} & Photographs \\
\hline NC: Baie de Ouano & $22^{\circ} 20^{\prime} \mathrm{S} ; 166^{\circ} 49^{\prime} \mathrm{E}$ & -- Oct 2004 & 1 & - & - \\
\hline NC: Baie de Tina & $22^{\circ} 16^{\prime} \mathrm{S} ; 166^{\circ} 30^{\prime} \mathrm{E}$ & 08 Sep 2005 & $1^{1,3}$ & [37] & Photographs; skull; skin sample \\
\hline NC: Baie de Sainte-Marie, Nouméa & $22^{\circ} 17^{\prime} \mathrm{S} ; 166^{\circ} 27^{\prime} \mathrm{E}$ & 05 Dec 2005 & $1^{1}$ & {$[38]$} & - \\
\hline \multicolumn{6}{|l|}{ Globicephala macrorhynchus } \\
\hline VA: Efate & - & -- Dec 1972 & 1 & {$[3]$} & Photograph \\
\hline LI: Saint-Joseph, Ouvéa & $20^{\circ} 26^{\prime} \mathrm{S} ; 166^{\circ} 18^{\prime} \mathrm{E}$ & -- Jun 1977 & 52 & $\begin{array}{l}{[2,39] \text {; }} \\
\text { M. Le Pêchoux (pers. comm.) }\end{array}$ & Photographs \\
\hline NC: Ilot Menoré, Isle of Pines & $22^{\circ} 32^{\prime} \mathrm{S} ; 167^{\circ} 25^{\prime} \mathrm{E}$ & 21 Sep 1997 & $1^{3}$ & {$[40]$} & Photograph \\
\hline NC: Baie de Gadji, Isle of Pines & $22^{\circ} 32^{\prime} \mathrm{S} ; 167^{\circ} 25^{\prime} \mathrm{E}$ & 24 Sep 1997 & $2^{4}$ & {$[40]$} & Photograph \\
\hline \multicolumn{6}{|l|}{ Globicephala sp. } \\
\hline NC: Récif Ouengip, Hienghène & $20^{\circ} 38^{\prime} \mathrm{S} ; 164^{\circ} 54^{\prime} \mathrm{E}$ & $\leq$ Jun 1965 & 1 & {$[13]$} & Photograph \\
\hline \multicolumn{6}{|l|}{ Kogia breviceps } \\
\hline NC: Port-Boisé & $22^{\circ} 21^{\prime} \mathrm{S} ; 166^{\circ} 57^{\prime} \mathrm{E}$ & -- Dec 1974 & 1 & {$[6]$} & Skull, MNHN 1976-37 \\
\hline NC: Plage de Plum & $22^{\circ} 18^{\prime} \mathrm{S} ; 166^{\circ} 40^{\prime} \mathrm{E}$ & 14 Sep 1985 & $1^{1}$ & {$[7,41]$} & Photographs \\
\hline NC: Vieux Touho & $20^{\circ} 46^{\prime} \mathrm{S} ; 165^{\circ} 10^{\prime} \mathrm{E}$ & 27 sep 1997 & 1 & {$[42]$} & Photograph \\
\hline NC: Baie de Magenta, Nouméa & $22^{\circ} 16^{\prime} \mathrm{S} ; 166^{\circ} 28^{\prime} \mathrm{E}$ & 02 Oct 1997 & 1 & {$[43]$} & Photographs \\
\hline NC: Baie de la Somme & $22^{\circ} 20^{\prime} \mathrm{S} ; 166^{\circ} 49^{\prime} \mathrm{E}$ & $\leq$ Jul 2002 & 1 & {$[44]$} & Skull \\
\hline \multicolumn{6}{|l|}{ Kogia sima } \\
\hline NC: Poum & $20^{\circ} 14^{\prime} \mathrm{S} ; 164^{\circ} 02^{\prime} \mathrm{E}$ & -- Jul 1972 & 1 & {$[6]$} & - \\
\hline NC: Gouaro Deva & $21^{\circ} 36 \mathrm{~S}^{\mathrm{S}} ; 165^{\circ} 20^{\prime} \mathrm{E}$ & 27 Mar 2004 & 1 & {$[21,45]$} & Photographs \\
\hline NC: Plage de Plum & $22^{\circ} 18^{\prime} \mathrm{S} ; 166^{\circ} 40^{\prime} \mathrm{E}$ & 28 Dec. 2005 & $3^{1,4}$ & T. Martinez (pers. comm.) & Photographs; skulls; skin samples \\
\hline \multicolumn{6}{|l|}{ Kogia sp. } \\
\hline LI: Ouvéa & - & $\leq 1997$ & 1 & G. Podlejska (pers. comm.) & Teeth \\
\hline \multicolumn{6}{|l|}{ Megaptera novaeangliae } \\
\hline NC: Thio & - & -- --- 1945 & 1 & Anonymous ${ }^{5}$ & Photographs \\
\hline NC: Grande Rade, Nouméa & $22^{\circ} 15^{\prime} \mathrm{S} ; 166^{\circ} 26^{\prime} \mathrm{E}$ & -- Jun 1989 & 1 & $\begin{array}{l}\text { [2]; B. Richer de Forges, } \\
\text { N. Baillon (pers. comm.) }\end{array}$ & Photographs \\
\hline Mesoplodon densirostris & & & & & \\
\hline NC: Ile Ouen & $22^{\circ} 28^{\prime} \mathrm{S} ; 166^{\circ} 48^{\prime} \mathrm{E}$ & -- Nov 1997 & $1^{3}$ & {$[10]$} & Teeth \\
\hline NC: Saint-Louis & $22^{\circ} 14^{\prime} \mathrm{S} ; 166^{\circ} 32^{\prime} \mathrm{E}$ & 07 Jun 2001 & 1 & {$[10]$} & Photographs \\
\hline Peponocephala electra & & & & & \\
\hline VA: Ravellec bay, Malakula & $16^{\circ} 31^{\prime} \mathrm{S} ; 167^{\circ} 36^{\prime} \mathrm{E}$ & 15 Nov 1972 & 32 & {$[4]$} & - \\
\hline VA: Ravellec bay, Malakula & $16^{\circ} 31^{\prime} \mathrm{S} ; 167^{\circ} 35^{\prime} \mathrm{E}$ & 16 Nov 1972 & 199 & {$[4]$} & Photographs \\
\hline LI: Baie du Santal, Lifou & $20^{\circ} 46^{\prime} \mathrm{S} ; 167^{\circ} 07^{\prime} \mathrm{E}$ & -- Mar 2003 & 1 & F. Pierre (pers. comm.) & Photographs \\
\hline Physeter macrocephalus & & & & & \\
\hline NC: Baie de Magenta, Nouméa & $22^{\circ} 16^{\prime} \mathrm{S} ; 166^{\circ} 28^{\prime} \mathrm{E}$ & -- --- 1934 & 1 & J. Rolland (pers. comm.) & Teeth \\
\hline NC: Ouaco & $20^{\circ} 51^{\prime} \mathrm{S} ; 164^{\circ} 28^{\prime} \mathrm{E}$ & $\leq$ Aug 1964 & 1 & {$[46]$} & Photograph \\
\hline
\end{tabular}




\begin{tabular}{|c|c|c|c|c|c|}
\hline NC: Tao reef & $20^{\circ} 34^{\prime} \mathrm{S} ; 164^{\circ} 70^{\prime} \mathrm{E}$ & $\leq$ Jan 1966 & 1 & {$[47]$} & Photograph \\
\hline LI: Baie de Hnatalo, Lifou & $20^{\circ} 45^{\prime} \mathrm{S} ; 167^{\circ} 16^{\prime} \mathrm{E}$ & 'early 70s' & 1 & B. Bonua (pers. comm.) & Bones \\
\hline NC: Nouville & $22^{\circ} 15^{\prime} \mathrm{S} ; 166^{\circ} 24^{\prime} \mathrm{E}$ & 06 Apr 1975 & $1^{2}$ & [48] & Photographs \\
\hline LI: Baie de Chateaubriand, Lifou & $20^{\circ} 53^{\prime} \mathrm{S} ; 167^{\circ} 15^{\prime} \mathrm{E}$ & -- Sep 1980 & 1 & $\begin{array}{l}\text { J.-C. Balouet (pers. conm. to } \\
\text { D. Robineau) }\end{array}$ & - \\
\hline NC: Cap Bayes, Poindimié & $20^{\circ} 57^{\prime} \mathrm{S} ; 165^{\circ} 25^{\prime} \mathrm{E}$ & 11 Nov 1980 & 1 & {$[49]$} & Photograph \\
\hline NC: Ouindo, Poindimié & $20^{\circ} 59^{\prime} \mathrm{S} ; 165^{\circ} 24^{\prime} \mathrm{E}$ & 12 Nov 1980 & 1 & {$[49]$} & - \\
\hline NC: Kohengone, Touho & $20^{\circ} 51$ 'S; $165^{\circ} 16^{\prime} \mathrm{E}$ & 15 Nov 1980 & 2 & {$[50]$} & - \\
\hline NC: Poé, Bourail & $21^{\circ} 37 \mathrm{~S} ; 165^{\circ} 24^{\prime} \mathrm{E}$ & 20 May 1989 & $1^{3}$ & {$[51,52]$} & Photographs \\
\hline NC: Récif des 5000 & $22^{\circ} 30^{\prime} \mathrm{S} ; 166^{\circ} 48^{\prime} \mathrm{E}$ & 04 Feb 1990 & 1 & G. Callejon (pers. comm.) & Mandible at MHM; tooth \\
\hline NC: Platier de Bourail & $21^{\circ} 39^{\prime} \mathrm{S} ; 165^{\circ} 28^{\prime} \mathrm{E}$ & 24 Sep 1995 & $1^{3}$ & [53] & Photographs \\
\hline NC: Passe de la Sarcelle & $22^{\circ} 27^{\prime} \mathrm{S} ; 167^{\circ} 14^{\prime} \mathrm{E}$ & 29 Nov 1997 & 2 & {$[54]$} & Photographs \\
\hline NC: Isle of Pines & - & -- --- 1998 & 1 & G. Podlejska (pers. comm.) & - \\
\hline NC: Mengalia Reef, Touho & $20^{\circ} 39^{\prime} \mathrm{S} ; 165^{\circ} 16^{\prime} \mathrm{E}$ & 18 Sep 1999 & 1 & {$[19,55]$} & Photographs \\
\hline LI: Baie de Chateaubriand, Lifou & $20^{\circ} 53^{\prime} \mathrm{S} ; 167^{\circ} 15^{\prime} \mathrm{E}$ & -- Mar 2001 & $1^{2}$ & P. Primot (pers. comm.) & - \\
\hline NC: Platier de Tangadiou, Koumac & $20^{\circ} 34^{\prime} \mathrm{S} ; 164^{\circ} 13^{\prime} \mathrm{E}$ & 06 Oct 2001 & 1 & {$[56]$} & Photograph \\
\hline NC: Ilot Bayes, Poindimié & $20^{\circ} 54 \mathrm{~S} ; 165^{\circ} 29^{\prime} \mathrm{E}$ & -- Dec 2001 & $1^{1}$ & [57] & Photograph \\
\hline NC: Ilot Goldfield, Saint-Vincent bay & $22^{\circ} 08^{\prime} \mathrm{S} ; 166^{\circ} 09^{\prime} \mathrm{E}$ & 10 Oct 2004 & $1^{3}$ & {$[58-60]$} & Photographs; skull \\
\hline NC: Ilot Carrey, Poum & $20^{\circ} 23^{\prime} \mathrm{S} ; 163^{\circ} 57^{\prime} \mathrm{E}$ & 02 Nov 2004 & 1 & {$[61]$} & Photograph \\
\hline \multicolumn{6}{|l|}{ Stenella longirostris } \\
\hline LI: Ouvéa & - & -- Dec 1972 & 2 & {$[3]$} & - \\
\hline LI: Baie de Takedji, Ouvéa & $20^{\circ} 27^{\prime} \mathrm{S} ; 166^{\circ} 36^{\prime} \mathrm{E}$ & 19 Jan 1994 & $\sim 30$ & {$[15,62]$} & Photographs \\
\hline VA: Erakor lagoon, Port-Vila & $17^{\circ} 46^{\prime} \mathrm{S} ; 168^{\circ} 18^{\prime} \mathrm{E}$ & 19 Dec 1994 & 36 & {$[17,18]$} & Photographs \\
\hline \multicolumn{6}{|l|}{ Tursiops aduncus } \\
\hline NC: Baie de Gadji, Isle of Pines & $22^{\circ} 32 \mathrm{~S} ; 167^{\circ} 25^{\prime} \mathrm{E}$ & -- --- 1977 & 1 & D. Robineau (pers. comm.) & Skull, MNHN 1979-75 \\
\hline NC: Isle of Pines & - & -- --- 1980 & 1 & D. Robineau (pers. comm.) & Skull, MNHN 1980-67 \\
\hline \multicolumn{6}{|l|}{ Tursiops sp. } \\
\hline NC: Baie de Magenta, Nouméa & $22^{\circ} 16^{\prime} \mathrm{S} ; 166^{\circ} 28^{\prime} \mathrm{E}$ & 25 Jul 1993 & $1^{2}$ & {$[2,14]$} & Photographs; frozen specimen \\
\hline NC: Baie de Sainte-Marie, Nouméa & $22^{\circ} 17 ' \mathrm{~S} ; 166^{\circ} 27^{\prime} \mathrm{E}$ & -- Sep 1994 & 1 & {$[16]$} & Photographs \\
\hline \multicolumn{6}{|l|}{ Unidentified cetacean } \\
\hline NC: Ilot Amédée & $22^{\circ} 29^{\prime} \mathrm{S} ; 166^{\circ} 28^{\prime} \mathrm{E}$ & 11 Aug 1979 & 2 & [63] & - \\
\hline
\end{tabular}

${ }^{1}$ Possible vessel strike; ${ }^{2}$ Calf; ${ }^{3}$ Bull; ${ }^{4}$ Female and calf; ${ }^{5}$ From two anonymous pictures of the stranding, with year and location 
Figure 1. Rorqual stranded in Kouaoua Cove on 27 June 1993 (images captured from an anonymous video footage deposited at MNHN). A. Dorsal-lateral view of right side of whole animal. B. Dorsal view of right side of head. C. Ventral view of right side of head and thorax.

Figure 2. Rorqual stranded in Baie de Tamanou on 20 May 1962 (photograph courtesy of M. Fels). 


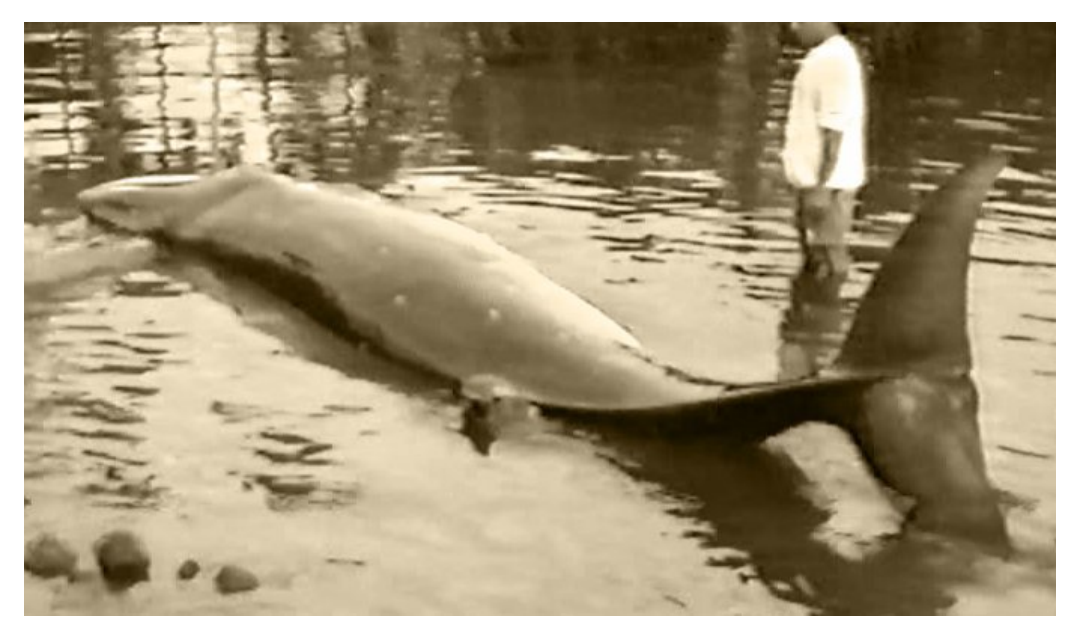

A

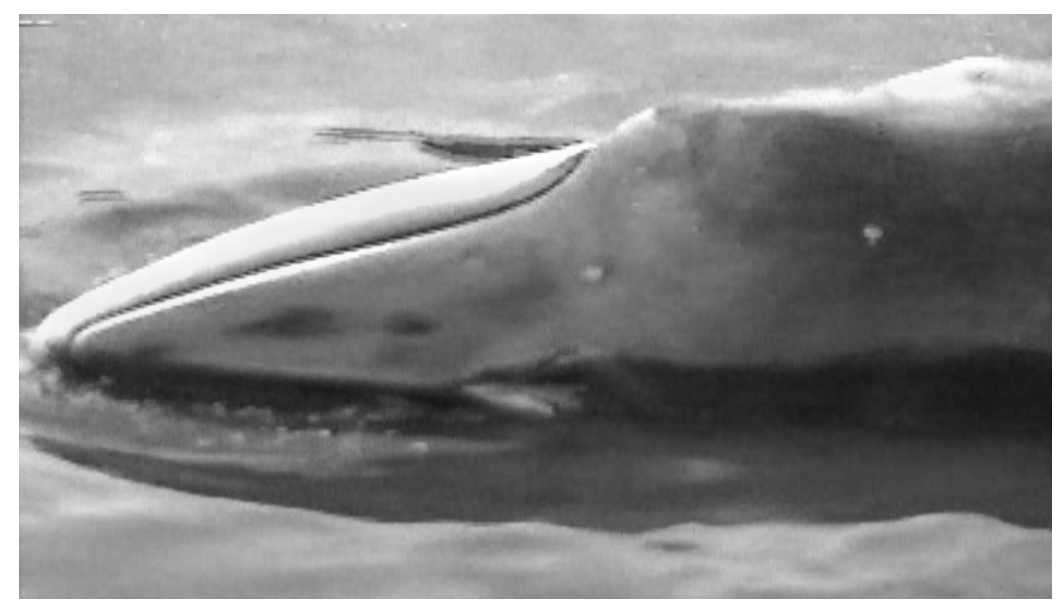

B

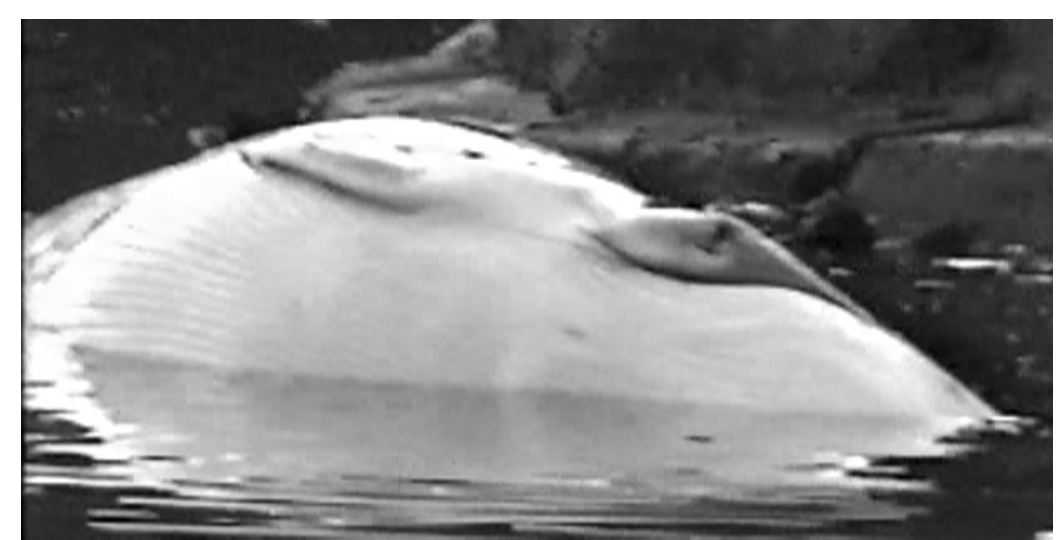

C 


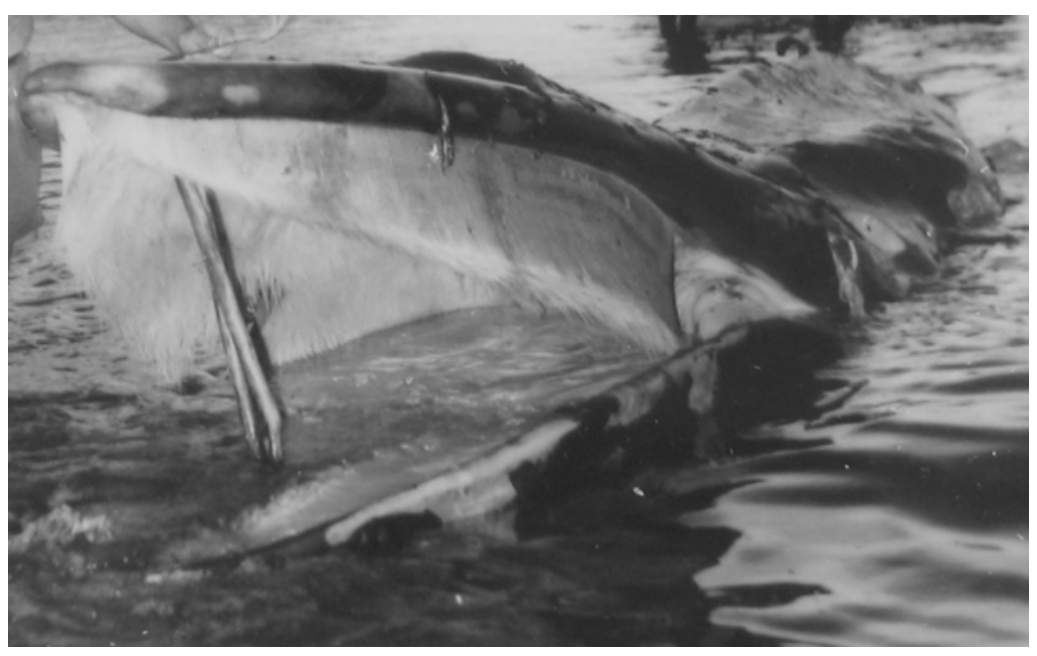

